\title{
Anticancer Properties of Hydroxycinnamic Acids -A Review
}

\author{
Luana Dalbem Rocha ${ }^{1}$, Mariana Costa Monteiro ${ }^{1} \&$ Anderson Junger Teodoro $^{1}$ \\ ${ }^{1}$ Food and Nutrition Program, Federal University of Rio de Janeiro State, Brazil. \\ Correspondence: Anderson Junger Teodoro, UNIRIO, Escola de Nutrição, Laboratório de Bioquímica \\ Nutricional. Av. Pasteur 276, Bloco II. 2 andar, Urca, Rio de Janeiro, RJ 22290-240, Brasil. Tel: 55-21-2542-7236 \\ or 55-21-2542-7276. E-mail: atteodoro@gmail.com
}

\author{
Received: September 25, 2012 Accepted: October 15, 2012 Online Published: October 30, 2012 \\ doi:10.5539/cco.v1n2p109 URL: http://dx.doi.org/10.5539/cco.v1n2p109
}

The authors declare that they have no competing interests

\begin{abstract}
Hydroxycinnamic acid compounds are an important source of antioxidants due to their ubiquitous occurrence in the plant kingdom and their characteristic activities. Due to their antioxidant activity, several researchers have attributed a probable role of these compounds in the prevention of various diseases associated with oxidative stress, such as cancer and cardiovascular diseases. Recent evidence suggests that these compounds may also act by other mechanisms in addition to the antioxidant capacity as modulating the activity of some specific enzymes and inhibit cell proliferation. This paper is a comprehensive review of the effects of hydroxycinnamic acids on cancer. The review encompasses the occurrence and bioavailability of these compounds evidences for their effects on cancer and the various mechanisms by which may exert their effects. There are several common mechanisms by which these chemicals exert their effects that could be conducive to additive, synergistic, or antagonistic interactions. These include effects on cellular differentiation, proliferation, and apoptosis; effects on proteins and enzymes that are involved in these processes at a molecular level, and other various effects through altered immune function and chemical metabolism.
\end{abstract}

Keywords: hydroxycinnamic acids, chlorogenic acids, antioxidant, cancer

\section{Introduction}

Phenolic compounds are secondary metabolites of plants widely distributed in foods and beverages of plant origin. They are secondary metabolites of these plants and are involved in defense against ultraviolet radiation or aggression by pathogens (Manach et al., 2004). These compounds may be classified in phenolic acids and flavonoids (Farah \& Donangelo, 2006).

Phenolic acids are molecules with one phenol ring bound with one or more hydroxyl groups, found in fruits, vegetables and products derivatives (Liu, 2004). These substances can be subdivided into two major groups: derivatives of hydroxybenzoic acids and derivatives of hydroxycinnamic acids (Figure 1) (Manach, Scalbert, Morand, Rémésy \& Jiménez, 2004).

The hydroxybenzoic acids (Figure 1A) are components of complex structures of tannins and lignins and are less abundant in plants consumed by humans (Manach et al., 2004). Its derivatives include $p$-hydroxybenzoic, protocatechuic, vannilic, syringic and gallic acids. On the other hand, the hydroxycinnamic acids (Figure 1B) are the largest class of phenolic compounds (Huang, Johanning \& O’Dell, 1986; Herrmann, 1989), represented by caffeic, $p$-coumaric and ferulic acids (Figure 1A) (Crozier, Jaganath \& Clifford, 2009; Lafay \& Gil-Izquierdo, 2008; Karakaya, 2004). Caffeic acid (CA) is the main hydroxycinnamic acid found in foods, mainly as chlorogenic acid (CGA).

Chlorogenic acids are formed by the esterification of (-)-quinic acid (Figure 2A) with one to four molecules of hydroxycinnamic acids (Clifford, 2000). The esters of this acid are formed preferably on carbon 5 of quinic acid (Figure 2B), but also on carbons 3 and 4, and less commonly on carbon 1 (Farah \& Donangelo, 2006). The main subclasses of CGA are the caffeoylquinic acids (CQA), feruloylquinic acids (FQA) and dicaffeoylquinic acids 
(diCQA), with at least 3 isomers per subclasses (Farah, Monteiro, Donangelo \& Lafay, 2008; Monteiro, Farah, Perrone, Trugo, \& Donangelo, 2007; Farah \& Donangelo, 2006).

a)<smiles>[R1]c1cc(C(=O)O)cc(O)c1O</smiles>

$\mathrm{R} 1=\mathrm{H}=$ Protocatechuic acid

$\mathrm{R} 1=\mathrm{OH}=$ Gallic acid b)<smiles>[R1]c1cc(C=CC(=O)O)ccc1O</smiles>

$\mathrm{R}_{1}=\mathrm{OH}=$ Caffeic acid

$\mathrm{R}_{1}=\mathrm{OCH} 3=$ Ferulic acid

$\mathrm{R}_{1}=\mathrm{H}=p$-coumaric acid

Figure 1. Chemical structures of hydroxybenzoic acids (A) and hydroxycinnamic acids (B)

CGA is found in many types of fruits (such as apples, blueberries, cherries, kiwis and plums), vegetables (chicory, potato and artichoke) and herbs (Ilex paraguariensis and Achyrocline satureioides), being coffee the main source in the Western diet (Marques \& Farah, 2009; Manach et al., 2004; Clifford, 2000).

a)<smiles>O=C(O)C1(O)CC(O)C(O)C(O)C1</smiles>

b)

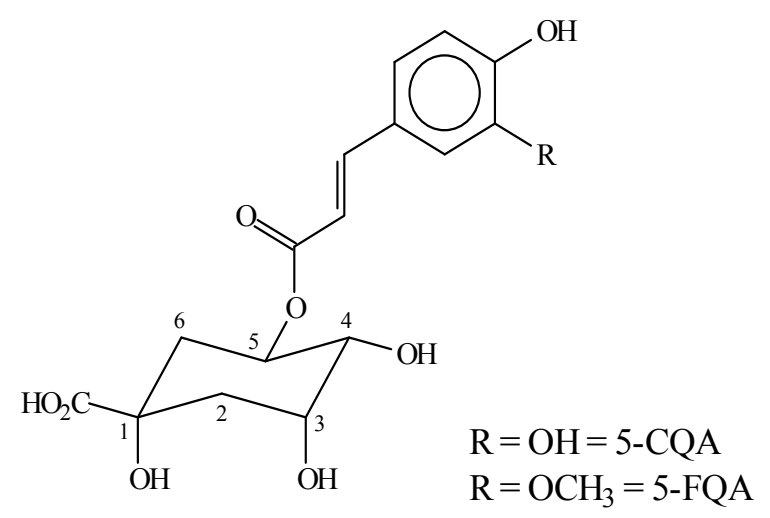

Figure 2. Chemical structures of (-)-quinic acid (A) and example of 5-isomers for CGA monoesters (B)

The presence of phenolic compounds in plants has been studied by participating in processes responsible for color, astringency and flavoring in different foods. Furthermore, due to their antioxidant activity, several researchers have attributed a probable role of these compounds in preventing of various diseases associated with oxidative stress, such as cancer and cardiovascular and neurodegenerative diseases (Manach et al., 2004; Johnston, Clifford, \& Morgan, 2003; Natella, Nardini, Giannetti, Dattilo \& Scaccini, 2002).

\section{Metabolism, Absorption and Bioavailability of Hydroxycinnamic Acids}

Until recently, only traces of CA and/or 5-CQA had been identified in both animal and human plasma (Lafay et al., 2006; Wittemer et al., 2005; Olthof, Hollman, Buijsman, Van Amelsvoort, \& Katan, 2003; Rice-Evans, Spencer, Schroeter, \& Rechner, 2000). However, currently it is known that the absorption of CGA is much higher than previously thought and studies have been shown that some individuals seem to be able to absorb up to $73 \%$ of the total of CGA ingested (Farah et al., 2008).

The maximum plasma concentration of total CGA in humans seems to be around $15 \mu \mathrm{mol} / \mathrm{L}$ and the predominant isomer of CGA, 5-CQA, has an average value of $6 \mu \mathrm{mol} / \mathrm{L}$. Besides the main isomers of CGA, it is known that 
some of its metabolites (caffeic acid, ferulic, isoferulic, and $p$-coumaric acid) are also bioavailable in humans with concentrations around $1.0 \mu \mathrm{mol} / \mathrm{L}$ (Farah et al., 2008; Monteiro et al., 2007). These values should be considered when carries out studies to evaluate the pharmacological properties of CGA, which often use concentrations a thousand times above these values.

Recently, Farah et al. (2008) and Monteiro et al. (2007) demonstrated for the first time that main isomers of CGA (3-, 4- and 5-CQA, 4- and 5-FQA, 3,4-, 3.5- and 4,5-diCQA) are bioavailable in the human body. These results indicated that a small percentage of CGA ingested are absorbed in stomach, been the major part absorbed and metabolized in the small intestine. Studies have shown that CGA follows intact toward intestine, where they would be conjugated, absorbed and/or metabolized (Duarte \& Farah 2011; Marques \& Farah, 2010; Monteiro, Marques \& Farah, 2010). In rats, Choudhury et al. (1999) suggested that at least a small amount of 5-CQA ingested is absorbed preferentially by jejunum when compared to ileum (Figure 3 ).

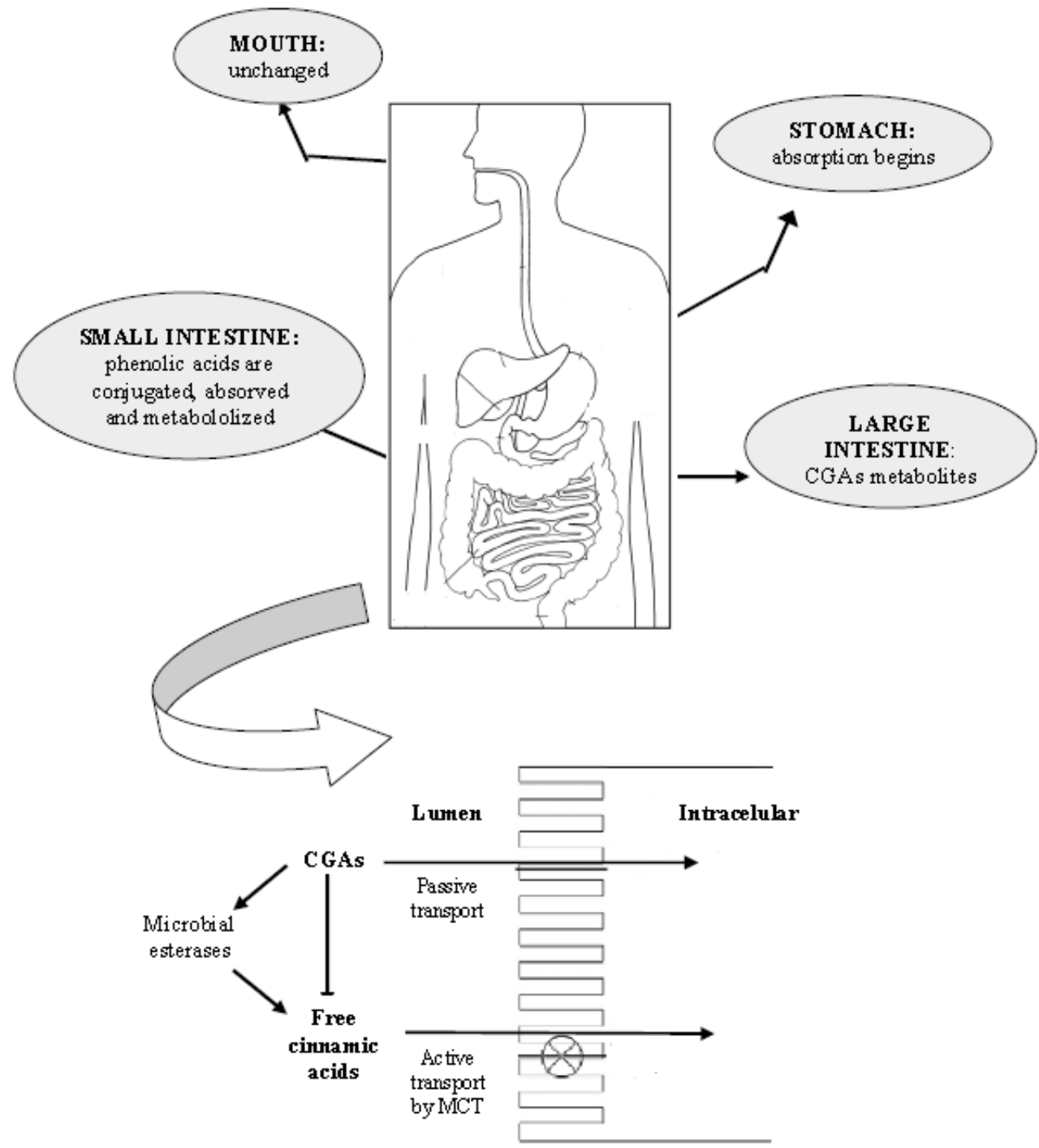

Figure 3. Chlorogenic and hydroxycinnamic acids absorption (Adapted from Bastos and Oliveira, 2011)

The CGA not absorbed by small intestine seem to follow until the large intestine, where they would suffer bacterial action. In fact, Couteau et al. (2001) reported that a large number of intestinal bacteria expressed esterase activity and are capable of hydrolyzing CGA to form caffeic acid and other metabolites in the intestine. These esterase activity are able to release cinnamic acid of CGA structure, which can then be absorbed and metabolized to its primary metabolites (caffeic acid, ferulic, isoferulic, and $p$-coumaric) (Couteau et al. 2001). Additionally, Konishi et al. (2004) demonstrated that CA liberated from CGA by intestinal mucosa esterase, is not only absorbed via paracellular diffusion but also actively absorbed by the monocarboxylic acid transporter 
(MCT) (Figure 3).

Part of CGA appears to be directly absorbed by the portal system following to the liver, where they would then metabolized, stored and/or released gradually by bile for an enterohepatic circulation (Baer-Dubowska \& Szaefer, 1998; Olthof et al., 2003; Manach et al., 2004). In fact, presence of CGA, CA, and ferulic and $p$-coumaric acids free in saliva, gastric and enteric fluids of human after $12 \mathrm{~h}$ of fasting has been reported in the literature (Monteiro \& Farah, 2008). This would agree with the hypothesis proposed by Booth et al. (1957), in which the author suggested that 5-CQA could stand being stored in the human body.

\section{Antioxidant Activity of Hydroxycinnamic Acids}

Phenolic compounds have been widely studied due to their influence on food quality. They are constituted by a large amount of substances, among them hydroxycinnamic acids, which have antioxidant properties, as a result of their chemical structure.

Hydroxycinnamic acids have been consistently associated with reduced risk of cardiovascular disease, cancer and other chronic diseases (Spencer, El Mohsen, Minihane \& Mathers, 2008). The ability of these substances in scavenges free radicals and pro-oxidant metals (antioxidant) partly explain this association. Recent evidence suggests that these compounds may also act by other mechanisms in addition to the antioxidant capacity as modulating the activity of some specific enzymes and inhibit cell proliferation (Manach, 2004). General antioxidant capability of the hydroxycinnamic acids in vitro can be expressed by the decreased malondialdehyde formation in several lipid peroxidation systems; scavenging of $\mathrm{O}_{2}$ and decreased rates of $\mathrm{OH}$ ' formation (Laranjinha et al., 1994).

Comparing the reducing power of hydroxycinnamic acids, CA proved to be a superior antioxidant compared with p-coumaric and ferulic acids, in inhibiting LDL oxidation and quenching of radicals and singlet oxygen (Gulçin, 2006). Chlorogenic acids and CA have an antioxidant potency in vitro and might inhibit the formation of mutagenic and carcinogenic N-nitroso compounds (Tapiero, Tew, Nguyen Ba, \& Mathé, 2002). CGA and CA showed ability to inhibit $\mathrm{N}$-nitrosation of an aromatic compound (2,3-diaminonaphthalene) via scavenging nitrogen sesquioxide $\left(\mathrm{N}_{2} \mathrm{O}_{3}\right)$ faster than most of other antioxidants (Kono et al., 1997).

Nakatani et al. (2000) demonstrated that some CGA isomers (3-, 4- and 5-CQA) isolated from prune showed antioxidant activity, such as elimination of superoxide radicals and inhibitory effect against oxidation of methyl linoleate. Additionally, Natella et al. (2002) evaluated the antioxidant capacity of coffee and black tea and showed that coffee has a higher antioxidant capacity than tea in hydrophilic medium. Whereas both drinks have phenolic compounds with different capabilities antioxidant activities, substances possibly responsible for these effects would be CA in coffee and catechins in tea.

In the same way, oxidative injuries can also perturb the cellular energy homeostasis by disrupting the mitochondrial integrity. Reactive oxygen species (ROS) can induce permeabilization of the mitochondrial membrane resulting in the release of apoptosis initiating factors (AIF), such as cytochrome c, Smac/DIABLO and dissipation of the mitochondrial membrane potential (Clifford, 2000). Furthermore, increased levels of ROS induce the activation of capases-9 and -3, which will lead to apoptosis (Ashkenazi \& Dixit, 1999).

Although the mechanism by which the hydroxycinnamic acids prevent oxidative stress are not yet fully elucidated, it seems to be mediated by translocation of Bad from the cytosol to the mitochondria where it dimerizes with Bcl-2 and Bcl-XL thereby neutralizing their mitochondrial stabilizing effect (Johnston, Clifford \& Morgan, 2003). Chlorogenic acids may prevent oxidative stress induced mitochondrial transition pore complex opening by decreasing production of $\mathrm{Bax}$ and $\mathrm{Bak}$ protein, favoring an increase in Bcl2-BclXL/Bax-Bak ratio (Johnston et al. 2003).

In vivo animal models, the physiological relevance of CA through a direct contribution to the antioxidant defense system was demonstrated by Nardini et al. (1997). Dietary supplementation of CA $(0.2$ and $0.8 \% \mathrm{w} / \mathrm{w})$ in rats resulted in a statistically significant increase of alfa-tocopherol both in plasma and in lipoprotein. Lipoproteins from caffeic acid-fed rats were more resistant than control to $\mathrm{Cu} 2+$ catalyzed oxidation.

\section{Role of Hydroxycinnamic Acids on Different Cancer Cells}

Cancer is already the leading cause of death in many high-income countries and is set to become a major cause of morbidity and mortality in the next decades in every region of the world, in spite of the enormous amount of research and rapid developments that have proceeded in the past decade. Therefore, considerable attention has been focused on chemoprevention as an alternative approach to the control of cancer (Kang, Shin, Lee, \& Lee, 2011). 
Evidence that hydroxycinnamic acids may have a potential inhibitory effect on cancer invasion and metastasis is increasingly being reported in the scientific literature (Weng \& Yen, 2012). During the last years many efforts have been made in order to elucidate the mechanisms involved by which hydroxycinnamic acids prevents cancer. These evidences are described below and summarized in Table 1. The possible mechanisms involved in anti-cancer effect of hydroxinamic acids is summarized in Figure 4 and we discuss depending on the site of cancer.

Table 1. Effects of hydroxycinnamic acids acids in different cancer cell lines and animal models

\begin{tabular}{|c|c|c|c|c|}
\hline Cancer type & Cell/Animal model & $\begin{array}{l}\text { Hydroxycinnamic } \\
\text { acids and derivates }\end{array}$ & Anticarcinogenic activities & References \\
\hline COLON & $\begin{array}{c}\text { RKO and HT-29 } \\
\text { colon cancer cell lines }\end{array}$ & $\begin{array}{c}\text { 3,4-, 3,5- and } \\
\text { 4,5-diCQA fraction }\end{array}$ & $\begin{array}{c}(-) \mathrm{COX}-2 / \mathrm{PGE}_{2} \\
\text { and iNOS/NO pathways }\end{array}$ & $\begin{array}{l}\text { Puangpraphant et } \\
\text { al., } 2011\end{array}$ \\
\hline COLON & $\begin{array}{c}\text { RKO and HT-29 } \\
\text { colon cancer cell lines }\end{array}$ & Caffeic acid & $\begin{array}{l}\text { (-) matrix metalloproteinase-9 } \\
\text { (MMP-9) activity }\end{array}$ & $\begin{array}{l}\text { Puangpraphant et } \\
\text { al., } 2011\end{array}$ \\
\hline COLON & $\begin{array}{c}\text { RKO and HT-29 } \\
\text { colon cancer cell lines }\end{array}$ & DiCQA fraction & $\begin{array}{c}\text { (-) proliferation of RKO and HT-29; } \\
\uparrow \text { ratio of Bax:Bcl-2 protein expression; } \\
\uparrow \text { Apoptosis }\end{array}$ & $\begin{array}{l}\text { Puangpraphant et } \\
\text { al., } 2011\end{array}$ \\
\hline COLON & CT26 cells & $\begin{array}{l}\text { Caffeic acid phenyl } \\
\quad \text { ester (CAPE) }\end{array}$ & $\begin{array}{c}(-) \text { cell invasion; } \\
\downarrow \text { MMP-2/-9 and VEGF productions; } \\
\downarrow \text { pulmonary metastatic capacity }\end{array}$ & Weng \& Yen, 2012 \\
\hline COLON & HCT116 cells & $\begin{array}{l}\text { Caffeic acid phenyl } \\
\text { ester (CAPE) }\end{array}$ & $\begin{array}{c}\uparrow \mathrm{G}_{0} / \mathrm{G}_{1} \text { phase cells, } \downarrow \mathrm{S} \text { phase ratio } \\
\text { and } \uparrow \quad \text { apoptosis rate }\end{array}$ & Wang et al., 2005 \\
\hline COLON & Caco- 2 cells & $\begin{array}{l}\text { Ferulic acid (FA) and } \\
\text { p-coumaric acid } \\
(\mathrm{p}-\mathrm{CoA})\end{array}$ & (-) cell cycle progression & Janicke et al., 2011 \\
\hline COLON & DLD-1 cell & $\begin{array}{l}\text { diCQA from sweet } \\
\text { potato leaf }\end{array}$ & $\downarrow$ cancer cell proliferation & Kurata et al., 2007 \\
\hline COLON & SW480 cells & $\begin{array}{l}\text { p-coumaric acid, } \\
\text { caffeic acid, ferulic } \\
\text { acid }\end{array}$ & $\begin{array}{c}\downarrow \text { numbers of viable cells and } \\
\text { colony formation }\end{array}$ & $\begin{array}{l}\text { Hudson et al., } \\
2000\end{array}$ \\
\hline GASTRIC & Kato III cell & $\begin{array}{l}\text { diCQA from sweet } \\
\text { potato leaf }\end{array}$ & $\downarrow$ cancer cell proliferation & Kurata et al., 2007 \\
\hline GASTRIC & $\begin{array}{l}\text { SNU638 and AGS } \\
\text { cell lines }\end{array}$ & $\begin{array}{l}\text { Ferulic acid (FA) and } \\
\text { caffeic acid (CA) }\end{array}$ & $\begin{array}{c}\text { Cytotoxic effects } \\
\uparrow \text { free radical scavenging }\end{array}$ & Kim et al., 2011 \\
\hline GASTRIC & Human gastric cancer & $\begin{array}{l}\text { Caffeic acid phenyl } \\
\quad \text { ester (CAPE) }\end{array}$ & $\begin{array}{l}\text { (-) MMP-9 expression } \\
\text { (-) invasive capacity }\end{array}$ & Wu et al., 2007 \\
\hline LIVER & AH109A cell line & Chlorogenic acids & (-) invasive capacity & Weng \& Yen, 2012 \\
\hline LIVER & Hep3B cells & Chlorogenic acids & (-) MMP-9 & Weng \& Yen, 2012 \\
\hline LIVER & AH109A cells & Caffeic acid & (-) invasion of AH109A cells in vitro & Weng \& Yen, 2012 \\
\hline LIVER & HepG2 cells & $\begin{array}{l}\text { Caffeic acid and } \\
\text { caffeic acid phenyl } \\
\text { ester (CAPE) }\end{array}$ & $\begin{array}{l}\text { (-) PMA-induced MMP-9 expression; } \\
\text { (-) binding activity of NF- } \kappa \mathrm{B}\end{array}$ & Weng \& Yen, 2012 \\
\hline LIVER & HEPG2 cells & $\begin{array}{l}\text { Caffeic acid and } \\
\text { caffeic acid phenyl } \\
\text { ester (CAPE) }\end{array}$ & $\begin{array}{l}\text { (-) proliferation (dose-dependent); } \\
\text { (-) MMP-9 expression }\end{array}$ & $\begin{array}{l}\text { Jaganathan et al., } \\
2009\end{array}$ \\
\hline LIVER & SKHep1 cells & $\begin{array}{l}\text { Caffeic acid phenyl } \\
\quad \text { ester (CAPE) }\end{array}$ & (-) MMP-2 and -9 expressions & Weng \& Yen, 2012 \\
\hline PROSTATE & DU145 & $\begin{array}{l}\text { Hydroxycinnamic } \\
\text { acids }\end{array}$ & $\begin{array}{l}\uparrow \text { apoptosis; } \\
\uparrow \text { cytotoxicity }\end{array}$ & $\begin{array}{l}\text { Szliszka et al., } \\
2011\end{array}$ \\
\hline PROSTATE & PC3 cells & Caffeic acid & $\begin{array}{l}\text { (-) invasion of human prostate } \\
\text { cancer cells }\end{array}$ & Weng \& Yen, 2012 \\
\hline
\end{tabular}




\begin{tabular}{|c|c|c|c|c|}
\hline BREAST & $\begin{array}{l}\text { MDA MB } 468 \text { and } \\
\text { HBL } 100 \text { cells }\end{array}$ & $\begin{array}{l}\text { P-coumaric acid, } \\
\text { caffeic acid, ferulic } \\
\text { acid, }\end{array}$ & $\begin{array}{l}\downarrow \text { numbers of viable cells } \\
\text { and colony formation }\end{array}$ & $\begin{array}{l}\text { Hudson et al., } \\
2000\end{array}$ \\
\hline BREAST & T47D cells & $\begin{array}{l}\text { Caffeic acid and } \\
\text { ferulic acid }\end{array}$ & $\begin{array}{l}\text { (-) cell growth (time and } \\
\text { dose-dependent) }\end{array}$ & Kampa et al., 2004 \\
\hline BREAST & T47D cells & Caffeic acid & $\uparrow$ apoptosis via the Fas/FasL system & Kampa et al., 2004 \\
\hline LUNG & Tumor cell lines & $\begin{array}{l}\text { Caffeic acid phenethyl } \\
\text { ester (CAPE) }\end{array}$ & $\begin{array}{c}\downarrow \text { tumor weight and number } \\
\text { of tumor nodules }\end{array}$ & $\begin{array}{l}\text { Nagaoka et al., } \\
2003\end{array}$ \\
\hline LUNG & Tumor cell lines & CAPE and analogues & $\begin{array}{c}\downarrow \text { tumor nodules in lung metastasis } \\
\text { formation }\end{array}$ & $\begin{array}{l}\text { Nagaoka et al., } \\
2003\end{array}$ \\
\hline LUNG & Primary tumors(mice) & Caffeic acid & $\begin{array}{l}\text { (-) proliferation, } \uparrow \text { macrophage } \\
\text { phagocytic activity and } \uparrow \text { gene } \\
\text { expression and production of } \\
\text { macrophage-related cytokines }\end{array}$ & Feng et al., 2010 \\
\hline
\end{tabular}

Legend: (-): inhibition, suppression

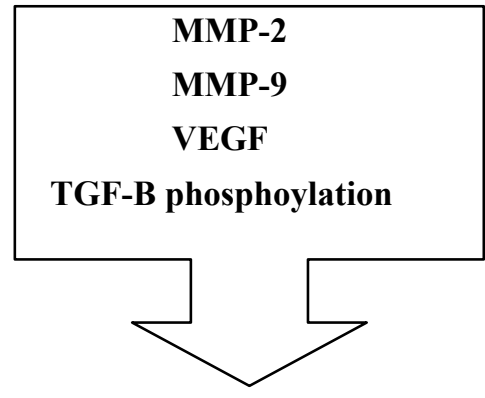

Metastasis suppression

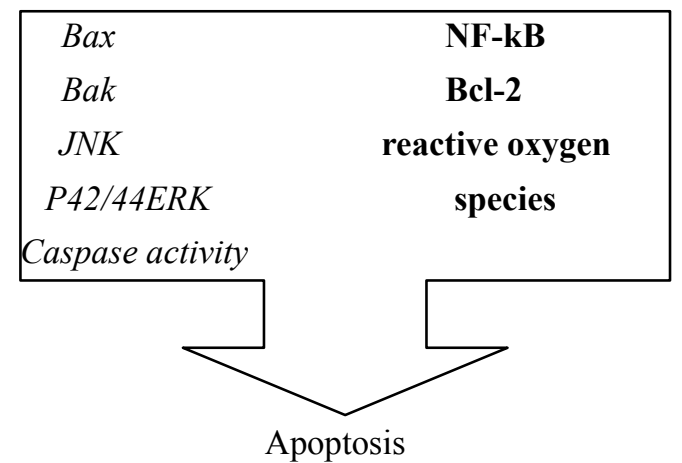

Apoptosis

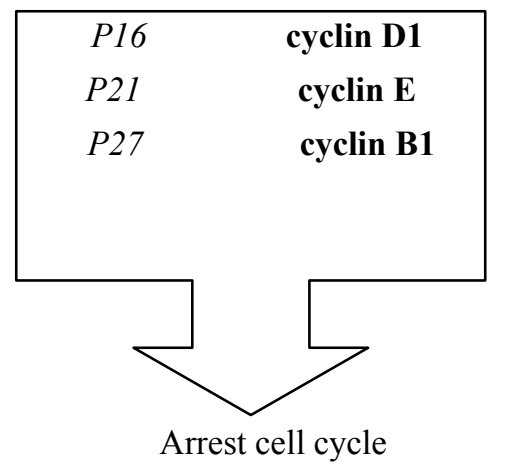

Figure 4. Potential mechanisms of anti-cancer activity of hydroxycinnamic acids

The signaling molecules being activated by hydroxycinnamic acids are shown in italic and those being suppressed by hydroxycinnamic acids are shown in bold

\subsection{Colon Cancer}

The colon cancer appears as the third most common type of cancer among men and the second among women. Studies have shown that the risk of developing colorectal cancer can be prevented by diet, with a decreased intake of dietary fat and an increased intake of cereal grains and dietary fiber (Parkin, Pisani \& Ferlay, 1999). Inflammatory bowel disease is another risk factor for development of colon cancer (Yio \& Itzkowitz, 2004). Inflammatory agents that suppress NF-kB or NF-kB-regulated products should have a potential in both the prevention and treatment of cancer. Nuclear factor $\mathrm{kB}(\mathrm{NF}-\mathrm{kB})$ is a transcription factor and essential component link between inflammation and cancer. In innate immune pre-neoplastic and malignant cells, NF-kB upregulates inflammatory cytokines and enzymes including cyclooxygenase-2 (COX-2) and inducible nitric oxide (iNOS), which are an important factor for the synthesis of inflammatory mediators prostaglandin E2 (PGE2), anti-apoptosis, angiogenesis and metastasis (Puangpraphant, Berhow, Vermillion, Potts \& Mejia, 2011).

Puangpraphant et al. (2011) demonstrated that 3,4-, 3,5- and 4,5diCQA fractions shown anti-inflammatory effect by suppressing the COX-2/PGE2 and iNOS/NO pathways. The diCQA fractions reduced nitric oxide (NO) by inhibiting iNOS enzyme. The capacity in reducing NO production of diCQA fraction was compared to CA. Besides this, CA showed an inhibitory effect of matrix metalloproteinase-9 (MMP-9) activity, which is known to be involved in tumor cell invasion and metastasis and anti-inflammatory activities. Additionally, it was shown that diCQA fractions inhibited proliferation of RKO and HT-29 human colon cancer cells. The diCQA fractions inhibited RKO and HT-29 cell proliferation by inducing apoptosis rather than arresting cell cycle. Apoptosis occurs through induction of the ratio of Bax:Bcl-2 protein expression and diCQA induced the cleavage of procaspase-3 to active caspase-3, which is a key step of apoptosis (Puangpraphant et al., 2011).

Invasion and metastasis are fundamental properties of malignant cancer cells. A number of proteolytic enzymes 
participating in these processes, which involve degradation of environmental barriers such as the extracellular matrix (ECM) and the basement membrane. Weng \& Yen (2012) showed that CT26 cells treated with caffeic acid phenyl ester (CAPE) exhibited not only cell invasion inhibition, but also a decrease in matrix metalloproteinase (MMP)-2/-9 and vascular endothelial growth factor (VEGF) productions. Intraperitoneal injection of CAPE into BALB/c mice reduced the pulmonary metastatic capacity of CT26 cells and decreased the plasma VEGF level.

On the other hand, when HCT116 cells were exposed to CAPE in different concentrations and times, CAPE displayed a strong growth inhibitory effect in a dose and time-dependent manner against HCT116 cells. Flow cytometry analysis showed that the ratio of $\mathrm{G}_{0} / \mathrm{G}_{1}$ phase cells increased, the $\mathrm{S}$ phase ratio decreased and apoptosis rate increased after HCT116 cells were exposed to CAPE (10, 5 and 2,5 mg/L) for $24 \mathrm{~h}$ (Wang et al., 2005).

Eberhardt et al. (2000) reported that apple extracts inhibited the proliferation of Caco-2 cells in dose-dependent manner. Additionally, McCann et al. (2007) demonstrated that the hydroxycinnamic acids components of apples were linked to inhibition of colon cancer in vitro. These phenolic compounds extracted from apples beneficially modulated three risk biomarkers of colorectal cancer in vitro without any cytotoxic effect. DNA damage was decreased (associated with tumor initiation), colonic barrier function was enhanced (associated with decreasing tumor promotion) and invasive potential was reduced (associated with reduced tumor metastatic potential).

Jaganathan et al. (2009) in your study indicated that phenylethyl caffeate (PEC), phenylethyl-3-methylcaffeate (PEMC), and phenylethyl dimethylcaffeate (PEDMC) present in the honey, inhibited azoxymethane (AOM)-induced colonic preneoplastic lesions, ornithine decarboxylase (ODC), tyrosine protein kinase (TPK), and lipoxygenase activity, which were relevant to the colon carcinogenesis. In addition, Janicke et al. (2011) investigated the effects of ferulic acid (FA) and $p$-coumaric acid $(p-\mathrm{CoA})$ treatment on global gene expression in Caco-2 colon cancer cells. A total of 517 genes was significantly affected by FA and 901 by p-CoA. They found that FA or p-CoA treatment delayed cell cycle progression and the expressions of a number of genes involved in centrosome assembly, such as RABGAP1 and CEP2, were upregulated by FA treatment as well as the gene for the S phase checkpoint protein SMC1L1 (Janicke et al., 2011).

\subsection{Gastric Cancer}

Gastric cancer is the second highest cause of cancer-related death in men and the fourth among women (Kim et al., 2011). The etiology of gastric cancer involves Helicobacter pylori (H. pylori) infection, chronic active or atrophic gastritis and intestinal metaplasia. Integrated research in molecular pathology has shown that gastric cancer is a chronic proliferative disease characterized by multiple genetic and epigenetic alterations, i.e., a disease of altered gene expression.

H. pylori colonization may also activate nuclear factor-kappa B (NF-kB). Thus, NF-kB has become a good therapeutic target for gastric cancer and numerous efforts are being made to develop safe NF-kB inhibitors. Among hydroxycinnamic acids, the most hopeful is caffeic acid phenethyl ester (CAPE), which is a phenolic antioxidant structurally related to 3,4-dihydroxycinnamic acid, and can be obtained from propolis, a honey constituent. H. pylori infection enhanced the activity of NF-kB and the expressions of MMP-9, IL-1b, and IL-8 in gastric adenocarcinoma cell line. However, the augmented responses could be significantly reversed by CAPE treatment. In addition, in vitro studies showed that CAPE inhibits tumor growth and the capacity for invasion. (Ribeiro \& Safatle-Ribeiro, 2007).

Nuclear expression of NF-kB was significantly more frequently observed in gastric cancer tissues than in nonmalignant gastric tissues. Wu et al. (2007) demonstrated that CAPE reduced MMP-9 expression induced by H. pylori and inhibited the invasive capacity of gastric cancer cells stimulated by IL-8 (inflammatory response) (Wu et al., 2007).

Recently, other natural products such as cinamic acids, coumarins and their components have been reported to have anti-H.pylori activity. Kim et al. (2011) investigated anti-gastritis activities of Cimicifuga heracleifolia $(\mathrm{CH})$ ethanol extract which contains ferulic acid and caffeic acid. Their results showed that hydroxycinnamic acids exhibited higher free radical scavenging activity than other constituents and inhibited colonization of $H$. pylori effectively. In addition, the cytotoxic effects of $\mathrm{CH}$ ethanol extract and its constituents were investigated in SNU638 and AGS gastric cancer cell lines. The results showed that caffeic acid was more sensitive in AGS cells than in SNU638 cells, suggesting that this compound have a direct anti-cancer effect and protects against gastric injury induced by H. pylori (Kim et al., 2011). Additionally, Kurata et al. (2007) isolated diCQA from sweet potato leaf and showed that diCQA depressed Kato III (human stomach carcinoma cell line) cell growth in a dose-dependent manner. 


\subsection{Liver cancer}

Epidemiological evidence suggests that moderate coffee consumption may help to reduce the risk of liver cancer, and the risk falls as coffee consumption rises. Literature indicates an inverse dose-dependent relationship between coffee consumption and the risk of hepatocellular carcinoma independent of its etiology (Gelatti et al., 2005).

Natella et al. (2002) demonstrated that the roasted coffee extract has phenolic compounds which are capable to increase the antioxidant activity in human plasma. Besides antioxidant activity of coffee constituents, studies show that polyphenols presented in coffee can activate the endogenous antioxidant system, leading to increased levels of hepatic glutathione, inhibition of lipid peroxidation and protection of rats liver from hepatotoxic action (Marsella, Di Benedetto, Vari, Filesi \& Giovannini, 2005).

Chlorogenic acids, however, revealed an anti-invasive activity in rat ascite hepatoma cell line (AH109A) and inhibited MMP-9 expression in Hep3B cells (Weng \& Yen, 2012). Additionally, CA demonstrated that suppresses invasion of AH109A cells in vitro. Treatment of HepG2 cells with CA and CAPE can suppress PMA-induced MMP-9 expression by inhibiting the binding activity of NF- $\mathrm{kB}$. CAPE exerts anti-invasive potential through inhibition of MMP-2 and -9 expressions, possibly by targeting NF- $\mathrm{kB}$ in SKHep1 cells (Weng \& Yen, 2012).

Jaganathan \& Mandal (2009) showed that both CA and CAPE promoted a dose-dependent inhibitory effect on HepG2 cell proliferation. In HepG2 cells, CA (concentration of $200 \mu \mathrm{g} / \mathrm{mL}$ ) reduced the cell viability to $61 \%$ compared to control, and treatment with CAPE (low concentration of $20 \mu \mathrm{g} / \mathrm{mL}$ ) reduced the viability to $72 \%$ compared of control. CAPE and CA suppressed MMP-9 expression by blocking NF-kB activity. They also confirmed that CA $(20 \mathrm{mg} / \mathrm{kg})$ and CAPE $(5 \mathrm{mg} / \mathrm{kg})$ repressed cell growth of tumor xenografts in nude mice as well as liver metastasis when administered subcutaneous or orally (Jaganathan \& Mandal, 2009).

At the same time, Carrasco-Legleu et al. (2006) showed a protective effect of 2-phenylethyl 3(3,4dihdroxyphenyl)-2-propenoate when a single dose was given before the initiation in rat hepatocarcinogenesis model. Administering CAPE in several doses during promotion caused a $90 \%$ decrease in the induction of c-glutamyl transpeptidase-positive (GGTp) foci on day 25; decreases in markers of preneoplastic lesions, GGT activity, and the amount of glutathione-S-transferase class Pi (GST-p) protein were also observed. The results showed a protective effect against induction of preneoplasic lesions and are related to antioxidant and chemopreventive effects reported for CAPE (Weng \& Yen, 2012).

\subsection{Prostate Cancer}

Chemoprevention of prostate cancer forms a three-pronged approach to reduce the burden of this common disease. Specifically, prevention aims to reduce disease incidence, thereby reducing the treatment-related side effects and potentially reduce disease-specific mortality. Xu \& Chang (2012) showed that phenolic content presents in food legumes commonly consumed exhibited a significant linear correlation with antioxidant activities and also possessed strong cancer cell proliferation inhibitory effects in nine different cancer cell lines. The phenolic antioxidants in beans may reduce oxidative stress in vitro and in vivo, may also prevent carcinogenesis and inhibit cancer cell proliferation (Xu \& Chang, 2012).

Szliszka et al. (2011) studied the action of ethanolic extract of propolis (EEP) and hydroxycinnamic acids in immunomodulatory, chemopreventive and antitumor effects in prostate cancer cells. It was observed cytotoxic and apoptotic activities of EEP against hormonesensitivity LNCaP and hormone-refractory DU145 prostate cancer cells. The results demonstrated that EEP and its components significantly sensitize to TRAIL-induced death in prostate cancer cells. The strongest cytotoxic effect on LNCaP cells was exhibited among other compounds by caffeic acid phenylethyl ester (CAPE).

Likewise, coffee may be associated with a reduced risk of prostate cancer. This contains many biological active compounds, including caffeine and chlorogenic acids that have potent antioxidant activity and can affect glucose metabolism and sex hormone levels. Wilsom et al. (2011) observed a weak inverse association between total coffee intake and incidence of prostate cancer. Men who consumed six or more cups per day had an $18 \%$ lower risk of prostate cancer compared with men who did not drink coffee.

Roles of insulin-like growth factors in prostate cancer biology are now well-established. Recent clinical and laboratory data support the hypothesis that insulin itself also influences the behavior of prostate cancer. Insulin levels have been associated with a greater risk of cancer progression or mortality among men diagnosed with prostate can-cer. Coffee contains CGA, which inhibit glucose absorption in the intestine and may favorably alter levels of gut hormones, which affect insulin response. Quinines, the roasting products of CGA, inhibit liver 
glucose production in experimental models (Wilsom et al., 2011).

The role of caffeine and other components of coffee, regular and decaffeinated coffee separately, was investigated in prostate cancer. Similar associations with lethal and advanced can-cers were found for both (Wilson et al., 2011). Additionally, Weng \& Yen (2012) demonstrated an effective inhibition of in vitro invasion of human prostate cancer cells (PC3) using CA treatment.

\subsection{Breast Cancer}

Antioxidant effects, steroid receptor binding, direct interaction with intracellular elements and signaling systems and, aryl hydrocarbon receptor (AhR) binding and modification of subsequent signaling pathways have been proposed as possible mechanisms for the mediation of the breast oncoprotective effect of hydroxycinnamic acids.

Eight hydroxycinnamic acids, including p-coumaric acid, caffeic acid, ferulic acid, sinapic acid, vanillic acid and methoxycinnamic acid, were identified in the extracts of two different types of rice (bran and brown extract). Bran extract decreased numbers of viable MDA-MB 468 and HBL 100 breast cells, colon-derived SW480 cells and human colonic epithelial cells. It also reduced colony formation of SW480 colon and MDA-MB 468 breast cells. CA $(50 \mu \mathrm{M})$ decreased the number of viable cells in all cancer cell lines studied, except HBL 100 (Hudson et al., 2000).

At the same time, Kampa et al. (2004) studied the antiproliferative action of caffeic acid, syringic acid, sinapic acid, protocatechuic acid, ferulic acid and 3,4-dihydroxy-phenylacetic acid (PAA) on T47D human breast cancer cells. The results showed a time and dose-dependent inhibitory effect on cell growth among compounds: caffeic acid $>$ ferulic acid $=$ protocatechuic acid $=$ PAA $>$ sinapic acid $=$ syringic acid. The antioxidative activity of these phenolic acids in T47D cells does not coincide with their inhibitory effect on tumoral proliferation. PAA induced an inhibition of nitric oxide synthase, while CA competes for binding and results in an inhibition of aryl hydrocarbon receptor-induced CYP1A1 enzyme, an enzyme induced by aryl hydrocarbon receptor activation. Both agents, however, induce apoptosis via the Fas/FasL system. These study show to note that necrotic cells were constantly low, indicating that these substances are not cytotoxic (Kampa et al., 2004).

Additionally, in MCF7 breast cancer cells, inhibitors of NO synthesis (NG-nitro-L-arginin methyl ester) and NO scavengers induced apoptosis, via a p53-associated pathway, while in T47D cells suppression of NO production triggers an induction of apoptosis via a FKHRL1 (FOXO3a) kinase pathway, independent of phosphoinositide 3-kinase-Akt and caspase-3 activation. In this study, phenolic acids exert a direct antiproliferative action (Kampa et al., 2004).

\subsection{Lung Cancer}

Lung cancer is the leading cause of cancer death in the world. Unfortunately, current therapy is still inadequate, and the 5-year survival rate for lung cancer remains poor. There is general agreement that the incidence of lung cancer is determined mainly by active cigarette smoking followed by occupational exposures. Epidemiological research has provided increasing evidence that dietary habits may play an important role in lung cancer etiology.

In this context, the consumption of an adequate diet rich in antioxidants are very important. Evidences have shown that ferulic acid (FA), a polyphenol very abundant in vegetables, acts as a potent antioxidant in vitro, due to its ability to scavenge free radicals. Furthermore, FA inhibited the expression and/or activity of cytotoxic enzymes including inducible nitric oxide synthase, caspases and cyclooxygenase-2. On this basis, FA has been proposed for the treatment of several age-related diseases such as cardiovascular diseases and cancer (Barone, Calabrese \& Mancuso, 2008).

Sudheer et al. (2007) demonstrated that ferulic acid (FA), at a concentration ranging to10 from $150 \mathrm{uM}$, counteracted nicotine-induced lipid peroxidation and GSH depletion in rat lymphocytes. In the same study, nicotine has been shown to significantly impair the antioxidant cell defense system, but co-administration of FA $(150 \mathrm{uM})$ counteracted the nicotine-induced decrease in superoxide dismutase catalase, glutathione peroxidase, vitamin $\mathrm{A}, \mathrm{E}$ and $\mathrm{C}$ contents and this antioxidant effect was comparable to that elicited by $\mathrm{N}$-acetylcysteine treatment.

On the other hand, Nagaoka et al. (2003) examined the antiproliferative activity of CAPE and its 20 analogues against six tumor cell lines. The oral administration of CAPE $(5 \mathrm{mg} / \mathrm{mice} / \mathrm{d})$ for $7 \mathrm{~d}$ after tumor inoculation decreased the tumor weight and the number of tumor nodules in lung by $50 \%$ compared to the control. Besides CAPE, 4-phenylbutyl caffeate, 8-phenyl-7-octenyl caffeate, 2-cyclohexylethyl caffeate and n-octyl caffeate at an oral dose of $2 \mathrm{mg} / \mathrm{mice} / \mathrm{d}$ caused a $55 \%, 43 \%, 55 \%$ and $35 \%$ reduction of the tumor nodules in their lung metastasis formation, respectively (Nagaoka et al., 2003). 
Feng et al. (2010) studied the efficacy of Prunella extracts in the prevention and treatment of lung cancer. Prunella is a herb rich in bioactive compounds, including phenol acids (caffeic acid). The efficacy of Prunella extracts from different regions was compared in vitro and in vivo, and the TNF- $\alpha$ activity in serum of tumor-bearing mice were also evaluated. Prunella showed significant activity in the prevention and treatment of lung cancer through antiproliferation, regulation of tumor cell division cycle, promotion of apoptosis, antioxidative effects, immune regulation, antimutagenic effects, stimulation of macrophage phagocytic activity and induction of gene expression and production of macrophage-related cytokines (Feng et al., 2010).

\section{Conclusion}

As discussed in this review, the cytoprotective effect of hydroxycinnamic acids in many experimental systems is well established. However, the potential use of supplemental hydroxycinnamic acids in the therapy of age-related human pathologies is still to be confirmed. The main concerns derive from the pharmacokinetics of hydroxycinnamic acids and in particular its poor bioavailability and metabolic fate. The first question to be addressed in further clinical studies should be the following: after oral supplementation in humans, does hydroxycinnamic acids reach tissue concentrations similar to those which have been shown to be effective in preclinical studies? Another confounding issue is that many studies have not defined the primary cellular site of action of hydroxycinnamic acids, with reported activities potentially caused by interaction with upstream binding partners, regulatory kinases, and receptors. Despite the knowledge about the antioxidant potential presented by hydroxycinnamic acids is of utmost importance studying the action of these substances in vivo, because no data were found regarding absorption, bioavailability conditions physiological plasma concentration and ideal for their protective activity against free radicals and cancer, although it has been found a high antioxidant potential these compounds in vitro.

\section{Authors' Contributions}

LD, MCM and JT wrote the paper; all authors have read and approved the final manuscript.

\section{References}

Ashkenazi, A., \& Dixit, V. M. (1999). Apoptosis control by death and decoy receptors. Current Opinion in Cell Biology, 11, 255-260. http://dx.doi.org/10.1016/S0955-0674(99)80034-9

Baer-Dubowska, W., Szaefer, H., \& Krajka-Kuzniak, V. (1998). Inhibition of murine hepatic cytochrome P450 activities by natural and synthetic phenolic compounds. Xenobiotica, 28(8), 735-743. http://dx.doi.org/10.1080/004982598239155

Barone, E., Calabrese, V., \& Mancuso, C. (2009). Ferulic acid and its therapeutic potential as a hormetin for age-related diseases. Biogerontology, 10(2), 97-108. http://dx.doi.org/10.1007/s10522-008-9160-8

Booth, J., \& Boyland, E. (1957). The biochemistry of aromatic amines. III. Enzymic hydroxylation by rat-liver microsomes. Biochem J., 66(1), 73-78.

Carrasco-Legleu, C. E., Sánchez-Pérez, Y., Márquez-Rosado, L., Fattel-Fazenda, S., Arce-Popoca, E. et al. (2006). A single dose of caffeic acid phenethyl ester prevents initiation in a medium-term rat hepatocarcinogenesis model. World J Gastroenterol, 12(42), 6779-6785.

Choudhury, R., Srai, S. K., Debnam, E., \& Rice-Evans, C. A. (1999). Urinary excretion of hydroxycinnamates and flavonoids after oral and intravenous administration. Free Radic. Biol. Med., 27, 278-286. http://dx.doi.org/10.1016/S0891-5849(99)00054-4

Clifford, M. N. (2000). Chlorogenic acids and other cinnamates-nature, occurrence, dietary burden, absorption

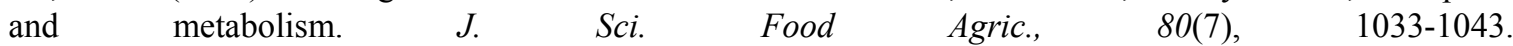
http://dx.doi.org/10.1002/(SICI)1097-0010(20000515)80:7<1033::AID-JSFA595>3.0.CO;2-T

Couteau, D., McCartney, A. L., Gibson, G. R., Williamson, G., \& Faulds, C. B. (2001). Isolation and characterization of human colonic bacteria able to hydrolyze chlorogenic acid. J. Appl. Microbiol., 90, 873-881. http://dx.doi.org/10.1046/j.1365-2672.2001.01316.x

Crozier, A., Jaganath, I. B., \& Clifford, M. N. (2009). Dietary phenolics: chemistry, bioavailability and effects on health. Nat. Prod. Rep., 26, 1001-1043. http://dx.doi.org/10.1039/b802662a

D’Archivio, M., Filesi, C., Di Benedetto, R., Gargiulo, R., Giovannini, C., \& Masella, R. (2007). Polyphenols, dietary sources and bioavailability. Ann. Ist. Super Sanitá, 43(4), 348.

Duarte, G. S., \& Farah, A. (2011). Effect of Simultaneous Consumption of Milk and Coffee on Chlorogenic Acids' Bioavailability in Humans. J. Agric. Food Chem., 59, 7925-7931. 
http://dx.doi.org/10.1021/jf201906p

Eberhardt, M. V., Lee, C. Y., \& Liu, R. H. (2000). Antioxidant activity of fresh apples. Nature, 405(6789), 903-904.

Farah, A., \& Donangelo, C. M. (2006). Phenolic compounds in coffee. Braz. J. Plant Physiol., 18(1), 23-36. http://dx.doi.org/10.1590/S1677-04202006000100003

Farah, A., Monteiro, M., Donangelo, C. M., \& Lafay, S. (2008). Chlorogenic Acids from Green Coffee Extract are Highly Bioavailable in Humans. J. Nutr., 138(12), 2309-2315. http://dx.doi.org/10.3945/jn.108.095554

Feng, L., Jia, X., Jiang, J., Zhu, M., Chen, Y. et al. (2010). Combination of Active Components Enhances the Efficacy of Prunella in Prevention and Treatment of Lung Cancer. Molecules, 15, 7893-7906. http://dx.doi.org/10.3390/molecules15117893

Gelatti, U., Covolo, L., Franceschini, M., Pirali, F., Tagger, A. et al. (2005). Coffee consumption reduces the risk of hepatocellular carcinoma independently of its aetiology: A case-control study. J. Hepatol., 42, 528-534. http://dx.doi.org/10.1016/j.jhep.2004.11.039

Gulçin, I. (2006). Antioxidant activity of caffeic acid (3,4-dihydroxycinnamic acid). Toxicology, 217, 213-220. http://dx.doi.org/10.1016/j.tox.2005.09.011

Herrmann, K. (1989). Occurrence and content of hydroxycinnamic and hydroxybenzoic acid compounds in food. Crit. Rev. Food Sci. Nutr., 28, 315-347. http://dx.doi.org/10.1080/10408398909527504

Huang, H. M., Johanning, G. L., \& O’Dell, B. L. (1986). Phenolic acid content of food plants and possible nutritional implications. J. Agric. Food Chem., 34, 48-51. http://dx.doi.org/10.1021/jf00067a013

Hudson, E. A., Dinh, P. A., Kokubun, T., Simmonds, M. S. J., \& Gesher, A. (2000). Characterization of potentially chemopreventive phenols in extracts of brown rice that inhibit the growth of human breast and colon cancer cells. Cancer Epidemiology, Biomarkers \& Prevention, 9, 1163-1170.

Jaganathan, S. K., \& Mandal, M. (2009). Antiproliferative Effects of Honey and of Its Polyphenols: A Review. Journal of Biomedicine and Biotechnology, 1-13. http://dx.doi.org/10.1155/2009/830616

Janicke, B., Hegardtb, C., Kroghc, M., Önningd, G., Åkessonef, B., Cirenajwis, H. M., \& Oredsson, S. M. (2011). The antiproliferative effect of dietary fiber phenolic compounds ferulic acid and p-coumaric acid on the cell cycle of Caco-2 cells. Nutrition and Cancer, 63(4), 611-22. http://dx.doi.org/10.1080/01635581.2011.538486

Johnston, K. L., Clifford, M. N., \& Morgan, L. M. (2003). Coffee acutely modifies gastrointestinal hormone secretion and glucose tolerance in humans: glycemic effects of chlorogenic acid and caffeine. Am. J. Clin. Nutr., 78(4), 728-733.

Kampa, M., Alexaki1, V., Notas, G., Nifli, A., Nistikaki, A., Hatzoglou, A., ... Castanas, E. (2004). Antiproliferative and apoptotic effects of selective phenolic acids on T47D human breast cancer cells: potential mechanisms of action. Breast Cancer Res, 6, 63-74. http://dx.doi.org/10.1186/bcr752

Kang, N. J., Shin, S., Lee, H. J., \& Lee, K. W. (2011). Polyphenols as small molecular inhibitors of signaling cascades in carcinogenesis. Pharmacology \& Therapeutics, 130, 310-324. http://dx.doi.org/10.1016/j.pharmthera.2011.02.004

Karakaya, S. (2004). Bioavailability of Phenolic Compounds. Crit. Rev. Food Sci. Nutr., 44(6), 453-464. http://dx.doi.org/10.1080/10408690490886683

Kim, M., Hwang, I. Y., Lee, J., Son, K. H., Jeong, C., \& Jung, J. (2011). Protective effect of Cimicifuga heracleifolia ethanol extract and its constituints against gastric injury. Journal of Health Science, 57(3), 289-292. http://dx.doi.org/10.1248/jhs.57.289

Konishi, Y., \& kobayashi, S. (2004). Transepithelial transport of chlorogenic acid, caffeic acid and their colonic metabolites in intestinal Caco-2 cell monolayers. $J$ Agric Food Chem., 52(9), 2518-2526. http://dx.doi.org/10.1021/jf035407c

Kono, Y., Kobayashi, K., Tagawa, S., Adachia, k., Uedaa, A., Sawaa, Y., ... Shibata, H. (1997). Antioxidant activity of polyphenolics in diets Rate constants of reactions of chlorogenic acid and caffeic acid with reactive species of oxygen and nitrogen. Biochimica et Biophysica Acta, 1335, 335-342. http://dx.doi.org/10.1016/S0304-4165(96)00151-1

Kurata, R., Adachi, M., Yamakawa, O., \& Yoshimoto, M. (2007). Growth suppression of human cancer cells by 
polyphenolics from Sweetpotato IIpomoea batatas L.) leaves. J. Agric. Food Chem., 55, 185-190. http://dx.doi.org/10.1021/jf0620259

Lafay, S., \& Gil-izquierdo, A. (2008). Bioavailability of phenolic acids. Phytochem. Rev., 7(2), 301-311. http://dx.doi.org/10.1007/s11101-007-9077-x

Lafay, S., Gil-Izquierdo, A., Manach, C., Morand, C., Besson, C. et al. (2006a). Chlorogenic acid is absorbed in its intact form in the stomach of rats. J. Nutr., 136, 1192-1197.

Laranjinha, J. A. N., Almeida, L. M., \& Madeira, V. M. C. (1994). Reactivity of dietary phenolic acids with peroxyl radicals: antioxidant activity upon low density lipoprotein peroxidation. Biochemical Pharmacology, 48(3), 487-494. http://dx.doi.org/10.1016/0006-2952(94)90278-X

Liu, R. H. (2004). Potential Synergy of Phytochemicals in Cancer Prevention: Mechanism of Action. J. Nutr., $134,3479-3485$.

Loeb, L. A., Emster, V. L., Warner, K. E., Abbotts, J., \& Laszlo, J. (1984). Smoking and Lung Cancer: An Overview. Cancer Res, 44, 5940-5958.

Manach, C., Scalbert, A., Morand, C., Rémésy, C., \& Jiménez, L. (2004). Polyphenols: food sources and bioavailability. Am. J. Clin. Nutr., 79, 727-747.

Marques, V., \& Farah, A. (2009). Chlorogenic acids and related compounds in medicinal plants and infusions. Food Chemistry, 113, 1370-1376. http://dx.doi.org/10.1016/j.foodchem.2008.08.086

Marques, V. X., \& Farah, A. (2010). Urinary excretion of chlorogenic acids and metabolites in humans after green mate (I. paraguariensis) consumption. The Faseb Journal, 24, 922.1.

Marsella, R., Di Benedetto, R., Vari, R., Filesi, C., \& Giovannini, C. (2005). Novel mechanisms of natural antioxidant compounds in biological systems: involvement of glutathione and glutathione-related enzymes. The Journal of Nutritional Biochemistry, 16(10), 577-586. http://dx.doi.org/10.1016/j.jnutbio.2005.05.013

McCann, M. J., Gill, C. I. R., Brien, G. O., Rao, J. R., McRoberts, W. C., Hughes, P., ... Rowland, I. R. (2007). Anti-cancer properties of phenolics from aplle waste on colon carciongenesis in vitro. Food and Chemical Toxicology, 45, 1224-1230. http://dx.doi.org/10.1016/j.fct.2007.01.003

Monteiro, M., Farah, A., Perrone, D., Trugo, L. C., \& Donangelo, C. (2007). Chlorogenic acid compounds from coffee are differentially absorbed and metabolized in humans. J. Nutr., 137, 2196-2201.

Monteiro, M. C., \& Farah, A. (2008). Caffeoylquinic and dicaffeoylquinic acids are excreted in both free and bound forms in human digestive fluids. Em: 22st International Conference on Coffee Science.

Monteiro, M. C., Marques, V. X., \& Farah, A. (2010a). Chlorogenic acids from green and roasted coffees are equally absorbed and metabolized by humans. The Faseb Journal, 24, 922.2.

Nagaoka, T., Banskota, A. H., Tezuka, Y., Harimaya, Y., Koizumi, K., Saiki, I., \& Kadota, S. (2003). Inhibitory Effects of Caffeic Acid Phenethyl Ester Analogues on Experimental Lung Metastasis of Murine Colon 26-L5 Carcinoma Cells. Biol. Pharm. Bull., 26(5), 638-641. http://dx.doi.org/10.1248/bpb.26.638

Nakatani, N., Kayano, S., Kikuzaki, H., Sumino, K., Katagiri, K., \& Mitani, T. (2000). Identification, quatitative determination and antioxidative activities of chlorogenic acid isomers in prune (Prunus domestica L.). $J$. Agric. Food. Chem., 48(11), 5512-5516. http://dx.doi.org/10.1021/jf000422s

Nardini, M., Natella, F., Gentili, V., Di Felice, M., Scaccini, C. et al. (1997). Effect of Caffeic Acid Dietary Supplementation on the Antioxidant Defense System in Rat: an in vivo Study. National Institute of Nutrition, 342(1), 157-160.

Natella, F., Nardini, M., Giannetti, I., Dattilo, C., \& Scaccini, C. (2002). Coffee drinking influences plasma antioxidant capacity in humans. J. Agric. Food Chem., 50, 6211-6216. http://dx.doi.org/10.1021/jf025768c

Oliveira, D. M., \& Bastos, D. H. M. (2011). Phenolic acids bioavailability. Quím. Nova, 34(6), 1051-1056. http://dx.doi.org/10.1590/S0100-40422011000600023

Olthof, M. R., Hollman, P. C. H., Buijsman, M. N. C. P., Van Amelsvoort, J. M. M., \& Katan, M. B. (2003). Chlorogenic acid, Quercetin-3-Rutinoside and Black Tea Phenol are extensively Metabolized in Humans. $J$. Nutr., 133, 1806-1814.

Parkin, D. M., Pisani, P., \& Ferlay, J. (1999). Global cancer statistics. CA: A Cancer Journal for Clinicians, 49, 33-64. http://dx.doi.org/10.3322/canjclin.49.1.33 
Puangpraphant, S., Berhow, M. A., Vermillion, K., Potts, G., \& Mejia, E. G. (2011). Dicaffeoylquinic acids in Yerba mate (Ilex paraguariensis St. Hilaire) inhibit NF-kB nucleus translocation in macrophages and induce apoptosis by activating caspases-8 and-3 in human colon cancer cells. Mol. Nutr. Food Res., 55, 1-14. http://dx.doi.org/10.1002/mnfr.201100128

Rechner, A. R., Spencer, J. P. E, Kuhnle, G., Hahn, U., \& Rice-Evans, C. A. (2001). Novel biomarkers of the metabolism of caffeic acid derivatives in vivo. Free Radical Biology and Medicine, 30(11), 1213-1222. http://dx.doi.org/10.1016/S0891-5849(01)00506-8

Ribeiro, U., \& Safatle-Ribeiro, A. V. (2007). Caffeic Acid Phenethyl Ester (CAPE) may be a Promising Adjuvant Treatment in Gastric Cancer. $J$ Clin Gastroenterol, 41(10), 871-873. http://dx.doi.org/10.1097/MCG.0b013e31806b5938

Rice-Evans, C. A., Spencer, J. P. E., Schroeter, H., \& Rechner, A. R. (2000). Bioavailability of flavonoids and potential bioactive forms in vivo. Drug Metabol. Drug Interact., 17, 291-310. http://dx.doi.org/10.1515/DMDI.2000.17.1-4.291

Spencer, J. P., El Mohsen, M. M. A., Minihane, A., \& Mathers, J. C. (2008). Biomarkers of the intake of dietary polyphenols: strengths, limitations and application in nutrition research. Br. J. Nutr., 99(1), 12-22. http://dx.doi.org/10.1017/S0007114507798938

Sudheer, A. R., Shanmugavelu, M., Chandran, K., Marimuthu, S., \& Menon, V. P. (2007). Protective effect of ferulic acid on nicotine-induced DNA damage and cellular changes in cultured rat peripheral blood lymphocytes : A comparison with n-acetylcysteine. Toxicology in vitro, 21(4), 576-585. http://dx.doi.org/10.1016/j.tiv.2006.11.006

Szliszka, E., Czuba, Z. P., Bronikowska, J., Mertas, A., Paradysz, A., \& Krol, W. (2011). Ethanolic Extract of Propolis Augments TRAIL-Induced Apoptotic Death in Prostate Cancer Cells. Evidence-Based Complementary and Alternative Medicine, 1-11. http://dx.doi.org/10.1093/ecam/nep180

Tapiero, H., Tew, K. D., Nguyen Ba, G., \& Mathé, G. (2002). Polyphenols: do they play a role in the prevention $\begin{array}{llll}\text { of human } & \text { 200-207. }\end{array}$ http://dx.doi.org/10.1016/S0753-3322(02)00178-6

Wang, D., Xiang, D., He, Y., Li, P., Wu, X., Mou, J. H., ... Zhang, Q. H. (2005). Effect of caffeic acid phenethyl ester on proliferation and apoptosis of colorectal cancer cells in vitro. World J Gastroenterol, 11(26), 4008-4012.

Weng, C., \& Yen, G. (2012). Chemopreventive effects of dietary phytochemicals against cancer invasion and metastasis: Phenolic acids, monophenol, polyphenol, and their derivatives. Cancer Treatment Reviews, 38, 76-87. http://dx.doi.org/10.1016/j.ctrv.2011.03.001

Williams, R. J., Spencer, J. P. E., \& Rice-Evans, C. (2004). Flavonoids: antioxidants or signaling molecules? Free Radic. Biol. Med., 36, 838-849. http://dx.doi.org/10.1016/j.freeradbiomed.2004.01.001

Wilson, K. M., Kasperzyk, J. L., Rider, J. R., Kenfield, S., Dam, R. M. V., Stampfer, M. J., .., Mucci, L. A. (2011). Coffee Consumption and Prostate Cancer Risk and Progression in the Health Professionals Follow-up Study. J Natl Cancer Inst., 103, 876-884. http://dx.doi.org/10.1093/jnci/djr151

Wittemer, S. M., Ploch, M., Windeck, T., Müller, S. C., Drewelow, B., Derendorf, H., \& Veit, M. (2005). Bioavailability and pharmacokinetics of caffeoylquinic acids and flavonoids after oral administration of Artichoke leaf extracts in humans. Phytomedicine, 12(1-2), 28-38. http://dx.doi.org/10.1016/j.phymed.2003.11.002

Wu, C. S., Chen, M. F., Lee, I. L., \& Tung, S. Y. (2007). Predictive role of nuclear factor-kB activity in gastric cancer: a promising adjuvant approach with caffeic acid phenethyl ester. J Clin Gastroenterol, 41, 894-900. http://dx.doi.org/10.1097/MCG.0b013e31804c707c

Xu, B., \& Chang, S. K. C. (2012). Comparative study on antiproliferation properties and cellular antioxidant activities of commonly consumed food legumes against nine human cancer cell lines. Food Chemistry, 134, 1287-1296. http://dx.doi.org/10.1016/j.foodchem.2012.02.212

Yio, X., \& Itzkowitz, S. H. (2004). Inflammation and Cancer IV. Colorectal cancer in inflammatory bowel disease: the role of inflammation. Am $J$ Physiol Gastrointest Liver Physiol, 287, G7-G17. http://dx.doi.org/10.1152/ajpgi.00079.2004 